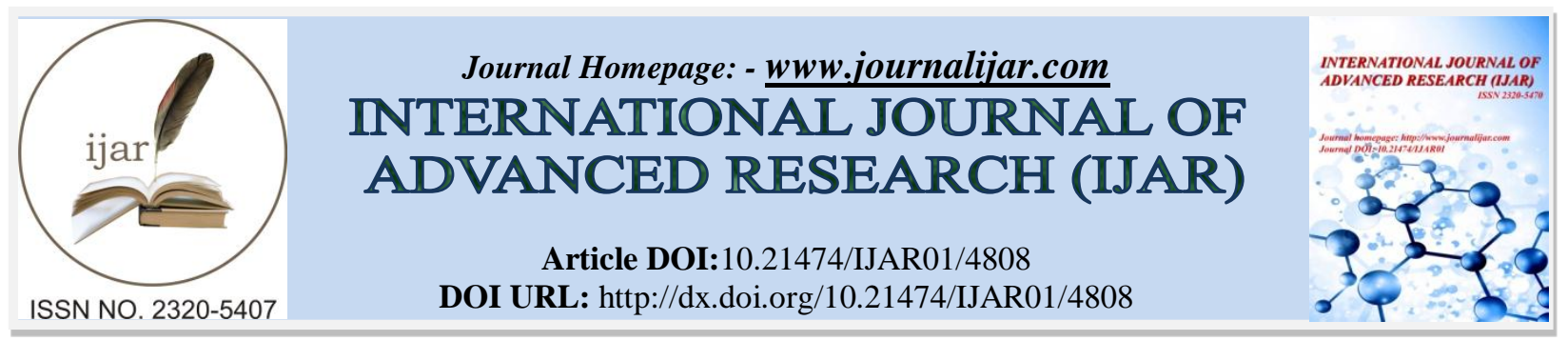

RESEARCH ARTICLE

\title{
SCREENING OF ROOT NODULE BACTERIA FROM WILD LEGUMES FOR THEIR POSSIBLE ROLE IN PLANT GROWTH PROMOTION.
}

\author{
Nidhi Gujar ${ }^{1 *}$, Shaishavee Saini ${ }^{2}$, Preeti Chandurkar ${ }^{1}$ Tanuja Murab $^{1}$, Anjali Choudhary ${ }^{1}$ and Nidhi \\ Tripathi ${ }^{2}$. \\ 1. Department of Biotechnology, Career college, Bhopal, India. \\ 2. Department of Biochemistry,Career college, Bhopal, India.
}

\section{Manuscript Info}

Manuscript History

Received: 10 May 2017

Final Accepted: 12 June 2017

Published: July 2017

Key words:-

Wild legumes, Plant growth promotion,

Root nodule bacteria

\section{Abstract}

In the present study, root nodule bacteria (RNB) were studied for their plant growth promoting (PGP) properties. For recovery of RNB wild leguminous plants viz., Abrus precatorious (A. precatorious), Crotolaria retusa (C. retusa), Crotolaria turnesia (C. turnesia), Desmodium sp. Gliricidia sp and Mimosa pudica (M. pudica) were collected from different areas of Bhopal. A total of 31 isolates ( 7 from A. precatorious, 3 from $C$. retusa, 4 from $C$. turnesia, 15 from Desmodium sp., 1 from Gliricidia sp. and 1 from M. pudica) were recovered and were studied for PGP activities viz., siderophore production, phosphate solubilization (P.solubilization), Indole acetic acid (IAA) production and ACC deaminase activity. $45.1 \%$ of the recovered isolates were positive for siderophore production with isolate DM1e showing maximum production i.e. $72.6 \mu \mathrm{g} \mathrm{ml}^{-1}$. About $22.5 \%$ of the isolates produced IAA with isolate DM1f showing the maximum production of $10 \mu \mathrm{g} \mathrm{m}{ }^{-1}$. P. solubilization and ACC deaminase activity was recorded in 54.8 and $87 \%$ isolates respectively. Further study on nitrogen fixation is underway. RNB such as rhizobia are known to promote plant growth by fixing nitrogen within root nodules and provide it to the plant for nutrition. Multifaceted beneficial effects can be obtained on plant growth and health by such RNB if they possess additional PGP properties as worked out in this study. Moreover, benefits can be obtained even if they fail to nodulate the plant (a constraint for rhizobia) but colonize the rhizosphere and compete with indigenous microbial population. Such microbes with multiple PGP properties could be developed as bioinoculants and have the potential to fetch the profit in growing biotechnology sector of India.

Copy Right, IJAR, 2017,. All rights reserved.

\section{Introduction:-}

Legumes are important in different agriculture and natural environment. Symbiosis between legumes and rhizobia are of considerable environmental and agricultural importance since they are responsible for most of the atmospheric nitrogen fixed on land.

Corresponding Author:-Nidhi Gujar.

Address:-Department of Biotechnology, Career college, Bhopal, India. 
RNB are soil borne micro-symbionts capable of forming nodules in plants of family Leguminosae. Within the nodules, the rhizobia fix atmospheric nitrogen and transport the fixed nitrogen to their hosts in the form of amino acid; this symbiosis is considered to be the most economic and ecofriendly resources for mankind and received an extensive study. The majority of bacteria that form root legume symbiosis belong to $\alpha$ proteobacteria (e.g. Azorhizobium, Bradyrhizobium, Mesorhizobium, Rhizobium, Sinorhizobium) (Sprent, 2001). Recently some $\beta$ proteobacteria, close to Burkholderia, Cupriavidus, Pseudomonas and Ralstonia and even some $\gamma$ proteobacteria able to form nitrogen fixing nodules with legumes, have been discovered (Sprent, 2007). Legumes also interact with a variety of plant growth promoting bacteria (PGPB) which are representatives of the genera Agrobacterium, Azospirullum, Bacillus, Burkholderia, Erwinia, Flavobacterium, Paenibacillus and Pseudomonas.

Rhizobia are important members of plant growth promoting rhizobacteria (PGPR) showing various PGP activities (Glick, 1994). Direct PGP activities include production of IAA and siderophore, P. solubilization, etc. (Deshwalet al., 2003). Possession of these PGP activities along with nitrogen fixation by rhizobia may account for better growth promotion in plants. Rhizobia are the first group of bacteria which have the ability to release IAA that can help to promote growth in plants (Mandalet al., 2007). Similarly, P solubilization activity has also been reported in Rhizobium (Mikanova and Kubat, 1999). Siderophore production may be of particular significance in rhizobia-legume symbiosis, since iron is required in nodule formation as well as synthesis of components required for nitrogen fixation, such as nitrogenase complex and leghaemoglobin

\section{Material and Method:-}

\section{Study site and sample Collection:-}

Samples (plants bearing root nodules) were collected from leguminous plants growing wildly in different areas of Bhopal such as Barkatullah University (B.U) campus, Ekant park and Swarna Jayanti park. The leguminous plant species collected for isolation of root nodule bacteria were Abrus precatorious, Crotolaria sp, Desmodium sp.,Gliricidia sp. and Mimosa pudica (Table 1).

Isolation of root nodulating bacteria from root nodules and their morphological Characterization:Isolation of bacteria from nodules (Fig 1B) was done following the standard procedure given by (Somasegaran and Hoben 1985). To ensure that the nodules were devoid of any microbial contamination, the surface sterilized nodules were placed on Yeast Extract Mannitol Agar (YEMA) plates (g/l; mannitol-10.0; $\mathrm{K}_{2} \mathrm{HPO}_{4}$ $0.5 ; \mathrm{MgSO}_{4} .2 \mathrm{H}_{2} \mathrm{O}-0.2$; NaCl-0.1; Agar-agar-20; Congo red dye-25 ppm; distilled water-1000 ml; pH-6.8) and incubated at $28^{\circ} \mathrm{C}$ overnight (Fig 1A). The nodules showing any microbial growth were discarded and only the clean nodules were selected for isolation of the microsymbiont. Individual nodules were crushed in $200 \mu 1$ of sterile distilled water in a test tube with the help of blunt ended forceps; the resultant turbid bacteroid suspension was streaked on YEMA plates and incubated at $28^{\circ} \mathrm{C}$ for growth of bacteria. From these cultures, gummy white transparent single cell colonies were picked up and re-streaked on YEMA plates to recover pure cultures. Colony morphology (shape, margin, elevation, colour) of the isolates were observed.

\section{PGPR Attributes:-}

\section{Siderophore Production:-}

For qualitative test, all the cultures were spot inoculated on Chrome Azurol Medium (Chrome Azurol Test); the plates were then incubated at $28 \pm 2^{\circ} \mathrm{C}$ for 3 days. The formation of orange halos around the bacterial cultures indicated positive test for siderophore production.

Quantification of siderophore produced in culture broth was carried in Standard succinate medium using extinction coefficient of siderophore ( $\mathrm{E}=16500, \mathrm{pH}$ 7.2) (Meyer and Abdallah, 1978). Pure cultures of selected isolates were grown in standard succinate broth for $24 \mathrm{~h} .1 \mathrm{ml}$ active culture was inoculated in $100 \mathrm{ml}$ standard succinate broth and flasks were incubated at $28 \pm 2^{\circ} \mathrm{C}(120) \mathrm{rpm}$. After $72 \mathrm{~h}$ of incubation, $10 \mathrm{ml}$ of culture was withdrawn and centrifuged at 10,000 rpm for $5 \mathrm{~min}$. The O.D of the supernatant was read at $400 \mathrm{~nm}$ and siderophore was quantified based on the extinction coefficient of pyoverdine as under:

\section{Siderophore $(\mathrm{mg} / \mathrm{L})=\mathbf{A}_{400} \mathrm{X}$ Mol. weight of compound}

Mol weight of Pyoverdine $=1,500 \mathrm{Da}$

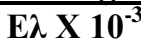

Extinction coefficient $(E \lambda)=16,500$ 
Test for phosphate solubilization was done on Pikovyskya agar medium. Test cultures were spot inoculated on plates containing Pikovyskya agar medium, the plates were then incubated at $28 \pm 2{ }^{\circ} \mathrm{C}$ for 3 days. The formation of clear zones around the bacterial cultures indicated positive test for phosphate solubilization. For the quantitative measurement of P, $100 \mathrm{ml}$ of Pikovyskaya broth containing tricalcium phosphate (TCP) were inoculated with $1 \mathrm{ml}$ of fresh culture $\left(10^{8}\right.$ cells $\left.\mathrm{ml}^{-1}\right)$ and incubated for $5 \mathrm{~d}$ on a shaker $(120 \mathrm{rpm})$ at $28 \pm 2{ }^{\circ} \mathrm{C}$. The culture broth was centrifuged $(12000 \mathrm{rpm}$ for $30 \mathrm{~min})$ and the amount of water soluble phosphate released into the supernatant was estimated by the chlorostannous-reduced molybdophosphoric acid blue method.

\section{IAA Production:-}

Indole acetic acid when react with $\mathrm{FeHClO}_{4}$ (Salkowasky reagent) gives stable pink colour. Salkowasky

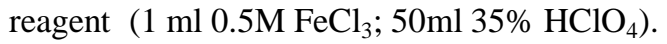

$\mathrm{M}_{9}$ minimal broth was prepared. $12.5 \mathrm{mg} / 250 \mathrm{ml}$ Tryptophan was added to media. $10 \mathrm{ml}$ broth was taken in the tubes and inoculated with test cultures, the tubes were incubated at $28 \pm 2^{\circ} \mathrm{C}$ for 3 days $(120 \mathrm{rpm})$. Culture broth was centrifuged at $10,000 \mathrm{rpm}$ for $5 \mathrm{~min}$ to remove cells. To $1 \mathrm{ml}$ cell free extract $2 \mathrm{ml}$ salkowasky reagent was added and tubes were incubated at room temperature for 30 min. Absorbance of pink coloured product was read at $530 \mathrm{~nm}$.

\section{ACC deaminaseActivity:-}

ACC (1-aminocyclopropane-1-carboxylate) deaminase producing bacterial isolates were detected qualitatively using Dworkin and Foster minimal medium simply known as DF medium (Dworkin and foster, 1958). DF medium was supplemented with 3mM 1-aminocyclopropane-1-carboxylate and bacterial isolates were streaked on the plates and incubated at $28^{\circ} \mathrm{C}$ for 72 hours. Simultaneously control was prepared by supplementing DF medium with ammonium sulfate $(2 \mathrm{~g} / \mathrm{l})$ to detect whether they utilized nitrogen source or not. Bacterial isolates were streaked upon it. Growth of bacterial isolates in medium supplemented with ACC indicated ACC deaminase production .

\section{Antagonistic Activity:-}

The isolates were screened against fungal pathogen ie. Fusarium oxysporum (F.oxysporum), Macrophomina phaseolina (M.phaseolina), Sclerotenia sclerotiorum (S.sclerotiorum) by in vitro dual plate assay (Huang and Hoes, 1976).

\section{Result:-}

\section{Isolation of root nodulatingBacteria:-}

A total of 31 isolates (7 from A. precatorius , 3 from $C$. retusa , 4 from C. turnesia , 15 from Desmodium sp., 1 from Glricidia sp. , 1 from $M$. pudica ) were isolated from 6 leguminous plant species.

\section{Colony morphology and Gram Reaction:-}

Colonies of all the isolates were round, mucoid, transparent/off white/white on YEMA amended with congo red dye $(25 \mathrm{ppm})$ dye (Fig.1C). All the isolates were Gram negative long and short rods (Fig 1D). Morphological characteristics of all the isolates are presented in (Table .1).

Table 1:- Colony morphology (colour, size, shape) and Gram reaction of recovered RNB from different wild legumes

\begin{tabular}{|c|c|c|c|c|c|c|}
\hline S.no & Source Plant & Isolates & Colony colour & Colony size & Gram reaction & Cell shape \\
\hline 1 & A. precatorious & AP1a & Off white & $2 \mathrm{~mm}$ & Gram negative & Short rods \\
\hline 2 & & AP1b & Off white & $1 \mathrm{~mm}$ & Gram negative & Short rods \\
\hline 3 & & AP1c & White & $1 \mathrm{~mm}$ & Gram negative & Long rods \\
\hline 4 & & AP1d & Off white & $1 \mathrm{~mm}$ & Gram negative & Long rods \\
\hline 5 & & AP2a & Off white & $<1 \mathrm{~mm}$ & Gram negative & Long rods \\
\hline 6 & & AP2b & Off white & $<1 \mathrm{~mm}$ & Gram negative & Short rods \\
\hline 7 & & AP2c & White & $1 \mathrm{~mm}$ & Gram negative & Short rods \\
\hline 8 & C. retusa & CR1a & White & $<1 \mathrm{~mm}$ & Gram negative & Long rods \\
\hline 9 & & CR1b & White & $2 \mathrm{~mm}$ & Gram negative & Long rods \\
\hline
\end{tabular}




\begin{tabular}{|c|c|c|c|c|c|c|}
\hline 10 & & CR1c & Trans parent & $2 \mathrm{~mm}$ & Gram negative & Short rods \\
\hline 11 & C. turnesia & CT1a & White & $1 \mathrm{~mm}$ & Gram negative & Long rods \\
\hline 12 & & CT1b & White & $1 \mathrm{~mm}$ & Gram negative & Short rods \\
\hline 13 & & CT1c & White & $1 \mathrm{~mm}$ & Gram negative & Long rods \\
\hline 14 & & CT1d & Off white & $1 \mathrm{~mm}$ & Gram negative & Long rods \\
\hline 15 & Desmodium $s p$. & DM1a & White & $2 \mathrm{~mm}$ & Gram negative & Short rods \\
\hline 16 & & DM1b & White & $2 \mathrm{~mm}$ & Gram negative & Long rods \\
\hline 17 & & DM1c & Off white & $1 \mathrm{~mm}$ & Gram negative & Short rods \\
\hline 18 & & DM1d & Off white & $1 \mathrm{~mm}$ & Gram negative & Short rods \\
\hline 19 & & DM1e & White & $1 \mathrm{~mm}$ & Gram negative & Long rods \\
\hline 20 & & DM1f & Off white & $1 \mathrm{~mm}$ & Gram negative & Long rods \\
\hline 21 & & DM1g & Off white & $1 \mathrm{~mm}$ & Gram negative & Short rods \\
\hline 22 & & DM2a & White & $1 \mathrm{~mm}$ & Gram negative & Long rods \\
\hline 23 & & DM2b & White & $2 \mathrm{~mm}$ & Gram negative & Short rods \\
\hline 24 & & DM2c & White & $2 \mathrm{~mm}$ & Gram negative & Short rods \\
\hline 25 & & DM2d & White & $1 \mathrm{~mm}$ & Gram negative & Long rods \\
\hline 26 & & DM2e & White & $1 \mathrm{~mm}$ & Gram negative & Long rods \\
\hline 27 & & DM2f & White & $1 \mathrm{~mm}$ & Gram negative & Short rods \\
\hline 28 & & DM2g & Off white & $1 \mathrm{~mm}$ & Gram negative & Long rods \\
\hline 29 & & DS1a & White & $1 \mathrm{~mm}$ & Gram negative & Long rods \\
\hline 30 & Gliricidia $s p$. & GG1a & Off white & $<1 \mathrm{~mm}$ & Gram negative & Short rods \\
\hline 31 & M. pudica & MP1a & White & $<1 \mathrm{~mm}$ & Gram negative & Long rods \\
\hline
\end{tabular}

Table 2:- PGPR attributes by RNB isolated from different wild leguminous plants

\begin{tabular}{|c|c|c|c|c|c|c|}
\hline S.No. & Isolates & $\begin{array}{c}\text { Siderophore } \\
\text { production }\end{array}$ & P.Sol." & IAA & $\begin{array}{c}\text { ACC } \\
\text { Deaminase }\end{array}$ & $\begin{array}{c}\text { Antagonism } \\
\text { against }\end{array}$ \\
\hline 1 & AP1a & - & $0.37 \pm 0.03$ & - & + & F. oxysporum \\
\hline 2 & AP1b & - & $0.23 \pm 0.02$ & - & + & \\
\hline 3 & AP1c & - & $0.16 \pm 0.03$ & - & + & F. oxysporum \\
\hline 4 & AP1d & - & $0.20 \pm 0.05$ & - & + & \\
\hline 5 & AP2a & - & $0.28 \pm 0.04$ & - & + & \\
\hline 6 & $\mathrm{AP} 2 \mathrm{~b}$ & - & $0.07 \pm 0.02$ & - & + & \\
\hline 7 & $\mathrm{AP} 2 \mathrm{c}$ & $8.75 \pm 0.12$ & $0.31 \pm 0.03$ & - & + & $\begin{array}{l}\text { M.phaseolina, } \\
\text { S.sclerotorium }\end{array}$ \\
\hline 8 & CR1a & $6.21 \pm 0.08$ & $0.39 \pm 0.05$ & - & + & \\
\hline 9 & CR1b & - & - & - & + & \\
\hline 10 & CR1c & $11.03 \pm 0.11$ & $0.22 \pm 0.07$ & - & + & $\begin{array}{l}\text { M.phaseolina, } \\
\text { S.sclerotorium }\end{array}$ \\
\hline 11 & CT1a & - & $0.32 \pm 0.06$ & - & + & \\
\hline 12 & CT1b & $4.48 \pm 0.09$ & - & - & + & \\
\hline 13 & CT1c & $13.15 \pm 0.19$ & - & - & + & \\
\hline 14 & CT1d & - & - & - & + & \\
\hline 15 & DM1a & $1.15 \pm 0.05$ & - & - & - & $\begin{array}{l}\text { M.phaseolina, } \\
\text { S.sclerotorium }\end{array}$ \\
\hline 16 & DM1b & - & - & $5.4 \pm 0.05$ & + & \\
\hline 17 & DM1c & $36.57 \pm 0.19$ & - & - & + & S. sclerotorium \\
\hline 18 & DM1d & - & $0.15 \pm 0.03$ & - & + & \\
\hline 19 & DM1e & $1.36 \pm 0.06$ & - & - & + & \\
\hline 20 & DM1f & $72.60 \pm 0.20$ & $0.47 \pm 0.03$ & $2.3 \pm 0.04$ & - & \\
\hline 21 & DM1g & - & $0.24 \pm 0.04$ & $10 \pm 0.18$ & + & S. sclerotorium \\
\hline 22 & DM2a & $6.81 \pm 0.11$ & $0.14 \pm 0.03$ & - & + & \\
\hline 23 & $\mathrm{DM} 2 \mathrm{~b}$ & $41.06 \pm 0.25$ & - & $4.9 \pm 0.05$ & + & \\
\hline 24 & DM2c & & & - & - & \\
\hline
\end{tabular}




\begin{tabular}{|c|c|c|c|c|c|c|}
\hline 25 & DM2d & - & $0.48 \pm 0.03$ & $4.85 \pm 0.08$ & + & \\
\hline 26 & DM2e & $24.51 \pm 0.10$ & - & - & + & \\
\hline 27 & DM2f & $10.72 \pm 0.20$ & - & $4.82 \pm 0.07$ & + & $\begin{array}{l}\text { M.phaseolina, } \\
\text { S.sclerotorium }\end{array}$ \\
\hline 28 & DM2g & - & - & - & - & \\
\hline 29 & DS1a & - & $0.17 \pm 0.02$ & - & + & $\begin{array}{l}\text { M.phaseolina, } \\
\text { S.sclerotorium }\end{array}$ \\
\hline 30 & GG1a & - & - & $2.5 \pm 0.07$ & + & \\
\hline 31 & MP1a & $12.15 \pm 0.20$ & $0.25 \pm 0.03$ & & + & \\
\hline
\end{tabular}

A ' + ' denotes positive test and '-' denotes negative test; Values represent mean \pm SE $(n=3)$ P.Sol-Phosphate solubilization, F.oxysporum-Fusarium oxysporum, M. phaseolina- Macrophomina phaseolina, S.sclerotoriumSclerotinia sclerotorium.

\section{PGPR Attributes:-}

In a plate assay for siderophore production $45 \%$ isolates showed positive results. Siderophore production ranged from 4.9-72.60 $\mu \mathrm{g} / \mathrm{ml}$, wherein, maximum amount of siderophore was produced by isolate DM1f $(72.60 \mu \mathrm{g} / \mathrm{ml})$ (Table 2, Fig.1E)

Only $22.5 \%$ isolates were found positive for IAA production. IAA production ranged between $2.3-10 \mu \mathrm{g} / \mathrm{ml}$ of IAA. Highest IAA production was recorded by isolate DM1g (10 $\mu \mathrm{g} / \mathrm{ml})$ (Table 2, Fig $1 \mathrm{~F})$

On Pikovaskya agar, 54.8\% isolates showed positive results for P solubilization by formation of clear zone around the bacterial colony. Based on solubilization efficiency, isolate DM2d was found to be most efficient P solubilizer under in vitro conditions. Results of P solubilization by RNB are presented in (Table 2, Fig 1G).

All the isolates were tested for ACC deaminase activity. $87 \%$ isolates showed positive results for the test.

Antagonistic activity of all the isolates were performed against three fungal pathogens viz., Macrophomina phaseolina, Fusarium oxysporum and Sclerotenia sclerotorium. Only 2 isolates AP1a \& AP1c showed zone of inhibition against $F$. oxysporum ,5 isolates AP2c,CR1c, DM1a, DM2f, DS1a showed antagonistic activity against both M. phaseolina and Sclerotenia sclerotorium. Two isolates DM1c and DM1g showed inhibition against S.sclerotorium (Table 2, Fig 1H)

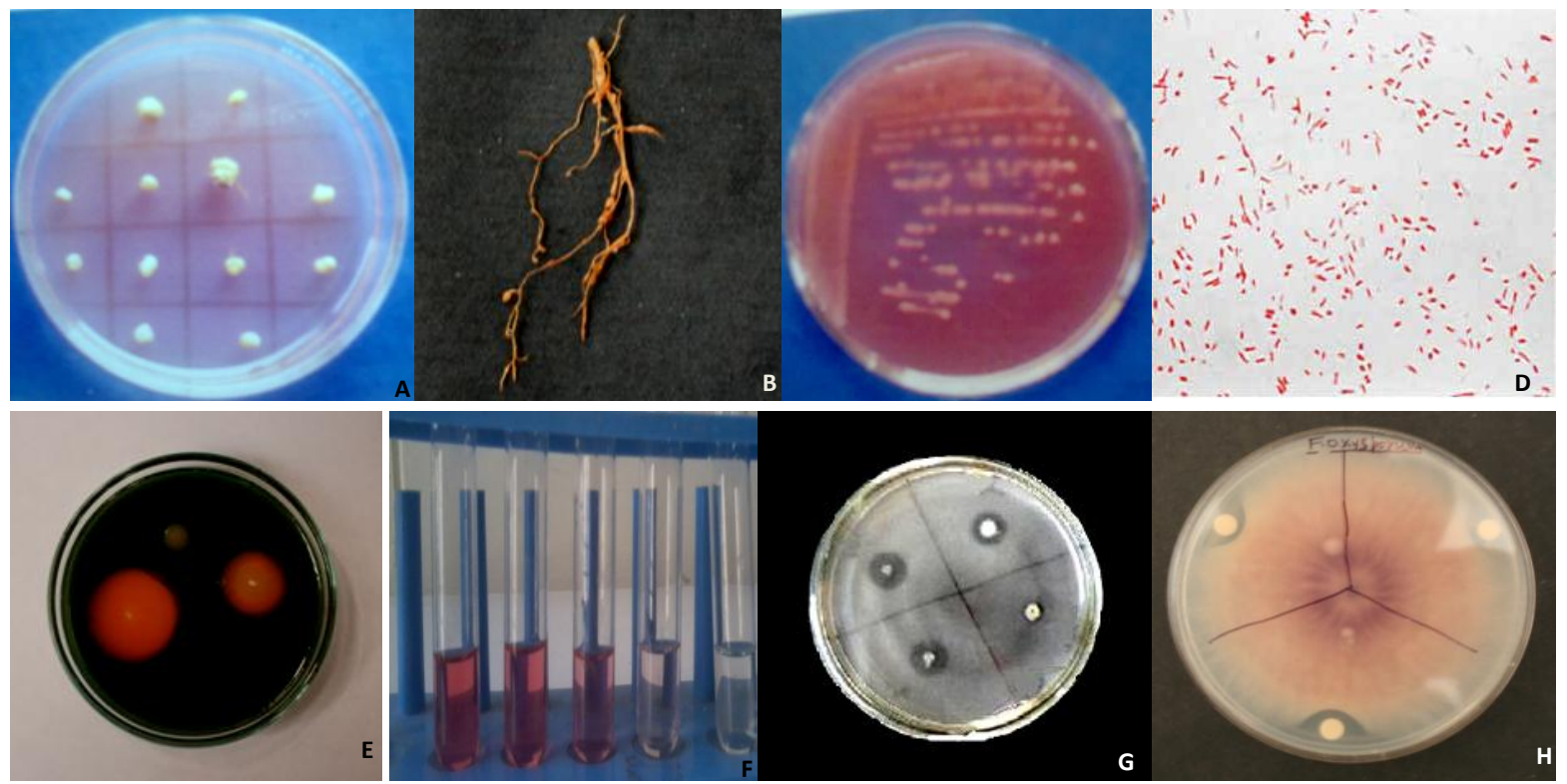

Fig.1:-Test for surface sterilization on YEMA (A); Root nodules of Mimosa sp.(B); Pure culture of RNB on YEMA(C); Gram staining of RNB (D); Siderophore production on CAS Medium (E); IAA production by RNB (F); P. solubilization on Pikovyaskya medium $(\mathrm{G})$; Antagonistic activity of RNB against $F$. oxysporum $(\mathrm{H})$ 


\section{Discussion:-}

It has been described frequently that a plant obtains almost everything directly from the soil to support growth. Therefore the soil structure must be physically capable of supporting the above-ground half of the plant through its developing root system as it grows. The soil needs to be maintained at an appropriate $\mathrm{pH}$, provide protection from toxic substances and pathogens and contain suitable water level. In addition to this all the essential mineral elements that plant requires are obtained from soil. Most of these elements are taken from the soil solution in their ionic form (White, 2003). Plant associated bacteria is probably one of the most important cause for improving growth and yields of various crops (Ali et al.2009).

Microorganisms having the mechanisms that facilitate nutrient uptake or increase nutrient availability or stimulate plant growth are commonly referred to as biofertilizers. The most well studied PGPR considered biofertilizers correspond to nitrogen fixation and utilization of insoluble forms of phosphate (Martinez et al. 2010).

$\mathrm{P}$ is an essential plant nutrient with low availability in many agricultural soils. Most of the insoluble $\mathrm{P}$ forms are present as aluminium and iron phosphate in acidic soils (Mulen, 2005) and calcium phosphates in alkaline soils (Goldstein and Krishnaraj ,2007).

The ability of rhizosphere bacteria to solubilize insoluble $\mathrm{P}$ minerals has been attributed to their capacity to reduce $\mathrm{pH}$ by excretion of organic acids (eg. Giuconate, citrate, lactate, and succinate and protons (during the assimilation of ammonium ions (Mullen, 2005).

Many important plant- microbial interactions center on the production of Auxin which is responsible for division, expansion and differentiation of plant cells and tissues and stimulates root elongation. The ability to synthesize IAA has been detected in many rhizobacteria as well as in pathogenic, symbiotic and free living bacterial isolates. ( Tsavkelova et al., 2006)

Various studies have demonstrated that plants treated with PGPR bacteria that produce ACC deaminase have increased their resistance to environmental stress (Grinchko and Glick, 2001).

In recent years, rhizobacteria containing ACC deaminase activity has been used to alleviate deleterious effects of ethylene under stressed conditions of high salt content, heavy metals, flooding and drought (Nadeem et al.,2010)

Treatment of $V$. radiata seeds with rhizobacteria exhibiting ACC deaminase activity significantly enhanced root length (upto 50\%) and number of nodules (upto47\%) (Akhtar and Ali 2011).

Indirect plant growth promotion includes the prevention of deleterious effect of phytopathogenic organisms (Glick and Pasternak 2003). This can be achieved by the production of siderophores, i.e. small iron binding molecules. In soil iron is found predominately as ferric ions, a form that cannot be directly assimilated by microorganisms. Siderophore production enables bacteria to compete with pathogen by removing iron from the environment (Hayat et al. 2010).

\section{Conclusion:-}

Assays on plant growth promoting properties, viz., P-solubilization, siderophore production, IAA production and ACC deaminase activity, revealed that many of isolated RNB have potential for the development of bioinoculants. These properties may promote growth, even if, these bacteria fail to nodulate the plant root. These RNB are of economic importance in low input sustainable agriculture, agroforestry and land reclamation.

Since these bacteria possess the plant growth promoting properties, these may be helpful in enhancing the yield and active principles of the selected medicinal plants, and thus may provide economic gains to the nurserymen and farmers of the state.

\section{Acknowledgement:-}

Financial support provided by Career College, Bhopal is gratefully acknowledged.

\section{Conflict Of Interest:-}

The authors have no conflict of interest to declare. 


\section{References:-}

1. Akhtar, S. and Ali, B (2011). Evaluation of rhizobacteria as non- rhizobial inoculants for mung beans. Aus J of crop sci.13:1723-1729.

2. Ali, B., Sabri, A.N., Ljung, K and Hasnain, S (2009). Auxin production by plant associated bacteria:impact on endogenous IAA content and growth of Triticum aestivum L. Letter Appl. Microbiol. 48:542-547.

3. Deshwal, V.K., Dubey, R.C and Maheswari, D.K (2003).Isolation of plant growth promoting Bradyrhizobium (Arachis) sp. with biocontrol potential against Macrophomina phaseolina causing charcoal rot of peanut. Curr sci. 84:443-448.

4. Dworken, M and Foster, J (1958). Experiments with some microorganisms which utilize ethane and hydrogen. J. Bacteriol.75: 592-601.

5. Glick, B.R and Pasternak, J.J (2003). Plant growth promoting bacteria , In: Glick, B.R., Pasternak, J.J.(eds) Molecular biotechnology principles and applications of recombinant DNA , $3^{\text {rd }}$ Edi, ASM Press, Washington, pp. 436-454.

6. Goldstein, A.H and Krishnaraj, P.U (2007). Phosphate solubilizing microorganisms vs. phosphate mobilizing microorganisms: what separates a phenotype from a trait? In: Velazquec E, Rodriguez- Barrueco C (eds) First international meeting on microbial phosphate solubilization . Springer, Dordre, pp-203-213.

7. Grichko, V.P and Glick, B.R (2001). Amelioration of flooding stress by ACC deaminase-containing plant growth promoting bacteria. Plant Physiol. Biochem. 39:11-17.

8. Hayat, R., Ali, S., Amara, U., Khalid, R and Ahamad, I (2010). Soil beneficial bacteria and their role in plant growth promotion. Annals of Microbiol. 10:1-18.

9. Huang, H.C and Hoes, J.A.C (2008). Penetration and infection of Sclerotinia sclerotiorum by Coniothyriumminiatus. Can. J. Bot. 54:506-410.

10. Jackson, J.E. (1932).The colorimetric determination of phosphorus. Biochem J. 26:292.

11. Mandal, S.M., Mondal, K.C., Dey, S and Pati, B.R (2007). Optimization of cultural and nutritional conditions for indole-3-acetic acid (IAA) production by a Rhizobium sp. Isolated from root nodules of Vigna mungo (L.) Hepper. Res. J. Microbial. 2:239-246.

12. Martinez-Viveros,O., Jorrquera, M.A., Crowly, D.E., Gajardo,G. and Mora, M.L (2010). Mechanism and practical considerations involved in plant growth promotion by Rhizobacteri. J. Soil sci. Plant Nutition. 3:293319.

13. Meyer, J.M and Abdallah, M.A (1978). The fluorescent pigment of Pseudomonas fluorescens : biosynthesis, purifuication and physiochemical properties. J. Gen. Microbiol. 107: 319-328.

14. Mikanova, O and Kubat, J (1999). The practical use of P-solubilizing activity of Rhizobium strains, Rostl.Vyr. 45:407-409.

15. Mullen, M.D (2005). Phosphorus in soils: biological interactions in: D. Hillel, C. Rosenzweig, D. Polwlson, K. scow, M. Singer, Sparks, D. (eds). Encyclopedia of soils in the Env. 3:210-215.

16. Nadeem, S.M., Zahir, Z.A., Naveed, M., Asghar, H. N and Arshad, M (2010). Rhizobacteria capable of producing Acc deaminase may mitigate salt stress in wheat, Soil Sci. Society of American J. 74: 533-542.

17. Somasegaran, $P$ and Hoben, H.J (1985). Methods in Legume-rhizobium Technology. NifTAL project and MIRCEN, Department of Agronomy, 2 edi. Soil Science Hawaii Institute Tropical Agriculture Human research, Univ Hawaii Manoa.

18. Sprent, J.I (2001). Nodulation in Legumes. Royal Botanical Gardens, Kew - Cromwell Press.

19. Sprent, J.I (2007). Evolving ideas of legume evolution and diversity: a taxonomic perspective on the occurrence of nodulation. New Phytol. 174:11-25.

20. Tsavkelova, E.A., Kilmova, S.Y., Cherdyntseva, T.A and Netrusov, A.I (2006). Microbial producers of plant growth stimulators and their practical use: a review. Appl. Biochem Microbiol. 42:117-126.

21. White, P.J (2003). Ion transport. In: Encyclopaedia of applied plant sciences (eds. B. Thomas, Murphy and Murray), 625-634. Academic Press, London. 